\title{
Ocular alterations in dogs naturally infected by Leishmania (Leishmania) chagasi
}

[Alterações oculares em cães infectados naturalmente por Leishmania (Leishmania) chagasi]

\author{
F.L.C. Brito ${ }^{1}$, L.C. Alves ${ }^{1}$, F.C.L. Maia ${ }^{1}$, E.S.C. Santos $^{1}$, J.L. Laus $^{2}$, I.M.J. Meunier ${ }^{1}$ \\ ${ }^{1}$ Universidade Estadual de Maringá - Umuarama, PR \\ ${ }^{2}$ Universidade Federal Rural de Pernambuco - Recife, Pe \\ ${ }^{3}$ Faculdade de Ciências Agrárias e Veterinárias - UNESP \\ Via de Acesso Professor Paulo Donato Castellane, s/n \\ 14884-900 - Jaboticabal, SP
}

\begin{abstract}
Ocular conditions, anti-Leishmania antibodies and total protein of the aqueous humor were studied in dogs naturally infected by Leishmania (Leishmania) chagasi. Fifty dogs were analyzed and assigned into two groups of 25 animals each. All animals were submitted to routine ophthalmic exam. Results showed that $76 \%$ of the affected animals presented ocular signs, being uveitis the predominant. The mean of total protein in the aqueous humor of animals with uveitis was higher $(\mathrm{P}<0.05)$ when compared to the mean of animals with other ocular signs or no clinical sign. The anti-Leishmania chagasi antibody values in plasma were superior to those found in the aqueous humor $(\mathrm{P}<0.05)$.
\end{abstract}

Keywords: dog, Leishmania (Leishmania) chagasi, aqueous humor, antibodies, protein

\section{RESUMO}

Estudaram-se as condições oculares, os anticorpos anti-Leishmania $e$ os valores de proteina total no humor aquoso de cães infectados naturalmente por Leishmania (Leishmania) chagasi. Analisaram-se 50 cães, divididos em dois grupos de 25 animais. Todos os animais foram submetidos a exame oftálmico rotineiro. Os resultados mostraram que $76 \%$ dos cães infectados apresentaram sinais oculares, sendo a uveite a alteração predominante. A média de proteina total no humor aquoso dos animais com uveite foi maior $(P<0,05)$, que a dos animais com outros sinais oculares ou sem qualquer sinal. Os valores de anticorpos anti-L. chagasi obtidos no plasma foram estatisticamente superiores aos encontrados no humor aquoso $(P<0,05)$.

Palavras-chave: cão, Leishmania (Leishmania) chagasi, humor aquoso, anticorpo, proteina

\section{INTRODUCTION}

In Brazil, canine visceral leishmaniasis (CVL), also known as canine calazar, is caused by $L$. chagasi and affects mainly domestic and wild canides and men. The infection by Leishmania sp. usually causes a systemic disease with chronic evolution, clinically apparent from three months to a few years after infection, and its severity will depend on depressed immunocompetence (Feitosa et al., 2000). Clinical signs such as anorexy, progressive weight loss, cutaneous lesions, peripheral lymphadenopathy, ocular lesions, chronic renal and liver diseases and poliartritis can be observed (Ferrer, 1999; Peña et al., 2000). There are several ocular conditions related to canine calazar. Blepharitis and keratoconjunctivitis are

Recebido em 24 de novembro de 2004

Aceito em 14 de fevereiro de 2006

*Autor para correspondência (corresponding author)

E-mail: fabiobrito@click21.com.br 
known to be the most frequent alterations, although granulomatous or lymphocytic uveitis, associated to corneal edema and synechiae, have prevailed (Garcia-Alonso et al., 1996; Peña et al., 2000).

Increased level of total plasmatic protein has been observed in CVL. Due to the ocular findings, particularly in the anterior segment of the eye (Puchol and Gonzáles, 1989; Molleda et al., 1993), the aqueous humor plays an important role on the course of the disease (Novales et al., 1994). According to aqueous humor alterations, antibody detection and dosage of protein level revealed an useful method in the diagnosis of ocular affections (Hazel et al., 1985; GarciaAlonso et al., 1996), despite it is not frequently used in canine leishmaniasis (Blogg and Colles, 1971).

Because of the importance of canine calazar on public health and its association to ophthalmopathies, particularly in endemic regions, this paper aimed to study the ocular conditions, specific antibodies and total protein dosage of the aqueous humor of dogs naturally infected by L. chagasi.

\section{MATERIAL AND METHODS}

Fifty dogs of several breeds and ages, males and females, coming from the metropolitan region of Recife and Bezerros cities, Pernambuco, Brazil, were analyzed. All the animals were clinically evaluated as well as submitted to routine ophthalmic examination. The animals were assigned into two groups composed by 25 dogs. The infected group (IG) was formed by animals positive for $L$. chagasi according to parasitological and serologic exams, presenting or not ocular alterations. The control group (CG) was composed by animals with negative results for L. chagasi according to parasitological and serologic exams, without clinical signs of systemic disease or ocular alterations. Parasitological diagnosis was accomplished after analysis of cutaneous scraps and bone marrow fluid, which was aspirated by punction in the sternum bone, besides the visualization of the amastigotas forms of $L$. chagasi. The serological diagnosis was done by indirect immunofluorescence ${ }^{1}$, as described by Camargo (1977).

Following recommendations of the World Health Organization (World..., 2003), the animals were euthanased. Immediately after, it was performed the paracentesis of the anterior chamber at limbal portion of both eyes to collect the aqueous humor using a $13 \times 4.5 \mathrm{~mm}$ gauge needle coupled to a $3 \mathrm{ml}$ disposable syringe. The samples were divided and disposed into $1 \mathrm{ml}$ plastic microtubes, which were identified and stored at the $-20^{\circ} \mathrm{C}$. Total protein was determined using the Coomassie blue technique for the analyses of microproteins (Bradford, 1976). The ELISA test was performed according to the instructions of the manufacturer for the diagnosis of canine calazar using S7 recombining peptides. The Goldmann-Witmer coefficient was obtained according to Hill et al. (1995).

For the statistical analysis, the Student (t) test was used to assess differences of protein concentration. Total proteins of the aqueous humor were studied using the analysis of variance. Means were compared using the Tukey test $(\mathrm{P}<0.05)$. The Signs test was applied to evaluate the results from the ELISA, with two variables: magnitude of the results and interpretation of positive and negative results using the Pearson's correlation coefficient.

\section{RESULTS}

From the 25 animals naturally infected by $L$. chagasi, $76 \%$ presented ocular lesions at ophthalmic examination. It was observed that, amongst the animals that presented ocular signs, $73.7 \%$ had only one type of alteration, while $26.3 \%$ showed more than one alteration in the same eye. Unilateral ocular alterations were observed in $10.5 \%$ of the dogs, while $89.5 \%$ presented bilateral alterations. It was also noted that the anterior chamber was affected in $76 \%$ and $4 \%$ of the animals presented alterations in both ocular chambers. In some cases, visualization of the inner eye structures was disturbed by opacifications of the aqueous humor.

\footnotetext{
${ }^{1}$ Conjugated antibody - ITI (Bio-Manquinhos) FIOCRUZ, Rio de Janeiro.
} 
The evaluation of the occurrence of ocular lesions showed that uveitis was the main alteration. This condition was bilateral in five dogs $(5 / 25)$. Two dogs (2/25) with uveitis presented hyphema (Fig. 1). Glaucoma secondarily to uveitis was found in one $(1 / 25)$ dog naturally infected by $L$. chagasi. Regarding other ocular alterations, $16 \%$ of the dogs developed blepharitis. Edema, seborrheic dry exudate and thickening with a fibrotic appearance of the eyelids were also observed in one animal (Fig. 2). The conjunctiva was affected in $40 \%(10 / 25)$ of the animals infected by $L$. chagasi. The lesion was restricted to the conjuctiva in $20 \%(2 / 10)$ of them (Fig. 3$)$. The

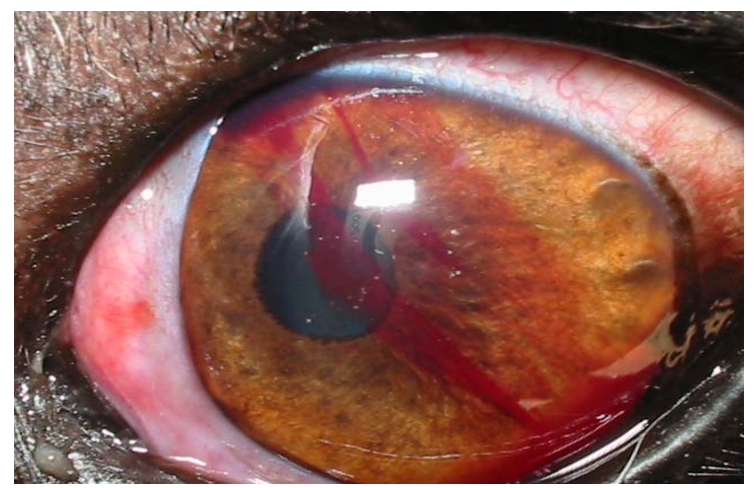

Figure 1. Discrete iris edema with hyphema in dog naturally infected by Leishmania (Leishmania) chagasi, Pernambuco State, Brazil, 2004.

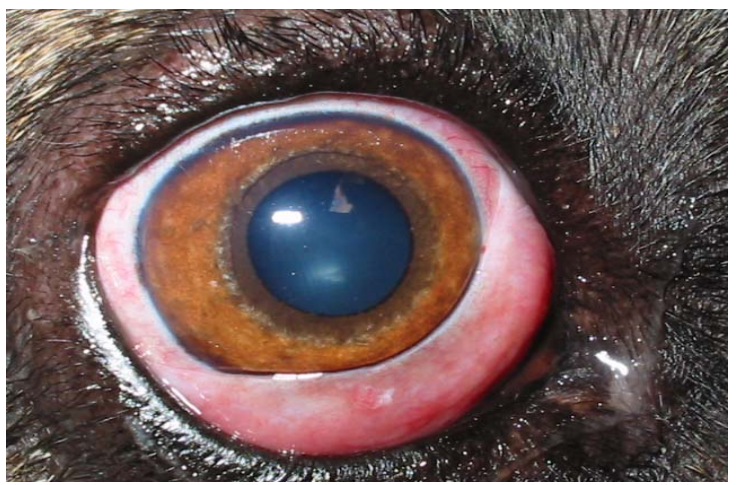

Figure 3. Conjunctivitis in a dog with visceral leishmaniasis. Note the prominent thickening of the ventral bulbar conjuctiva, Pernambuco State, Brazil, 2004. involvement of the conjunctiva and cornea was observed in $20 \%(5 / 25)$ of the animals (Fig. 2), being keratitis the second most frequent finding associated to conjunctivitis. From the animals with keratoconjunctivitis, 8\% (2/25) presented the keratoconjunctivitis sicca (Fig. 4). Isolated corneal lesions were observed in $12 \%(3 / 25)$ of the dogs. Two animals presented keratitis and four dogs exhibited superficial corneal ulceration with a focused edema. Coriorretinitis was observed in only one animal. Twenty per cent $(5 / 25)$ of the animals did not exhibit any ocular problems.

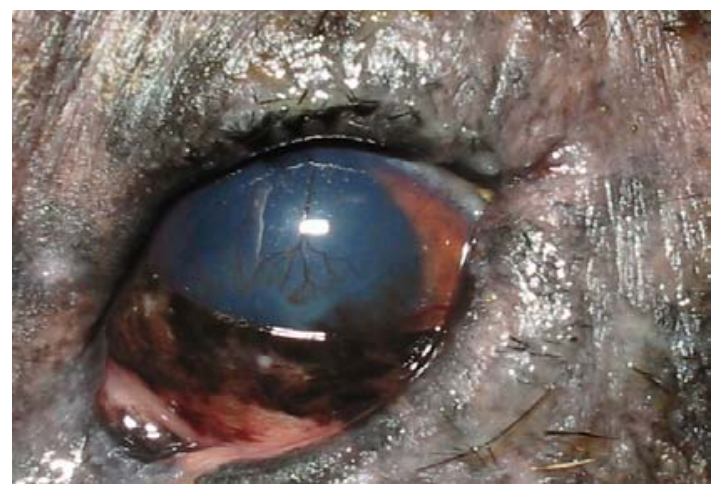

Figure 2. Diffuse blepharedema with periocular alopecia, seborrheic dry exudate and thicknening fibrotic eyelids, keratitis with corneal edema, pigmentation and neovascularization in a dog with visceral leishmaniasis, Pernambuco State, Brazil, 2004.

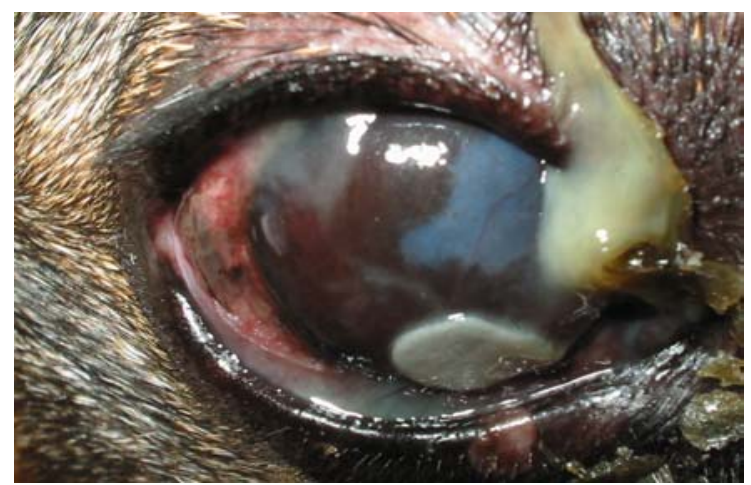

Figure 4. Keratoconjunctivitis sicca in a dog with visceral leishmaniasis. Note mucopurulent exsudate, diffuse corneal edema, neovascularization and corneal pigmetation, Pernambuco State, Brazil, 2004. 
The mean protein level was the same for both right and left eyes, $(P>0.05)$. Comparing the means of infected and control groups, a significant increase of the values for the infected IG group was observed (Table 1). When the aqueous humor protein concentration of dogs with CVL were evaluated, according to ocular signs (Table 2), differences between the mean values $(\mathrm{P}<0.05)$ were found. The mean of total protein concentration of the aqueous humor in animals with uveitis was higher $(\mathrm{P}<0.05)$ when compared to animals with other ophthalmopathies or without ocular alterations. It was also observed a difference $(\mathrm{P}<0.05)$ between animals clinically healthy and those with leishmaniasis, regardless of ocular lesion. Dogs presenting canine visceral leishmaniasis had total protein values seven times higher than those found in animals of the control group. It was interesting to note that the highest variability of protein values was observed amongst individuals without ocular signs (Table 2). However no difference was found amongst animals that presented others signs besides uveitis.

Statistical analysis of the anti-L. chagasi $\operatorname{IgG}$ concentration, in the aqueous humor as measured by optical density, showed similarity in both right and left eyes. However values obtained from plasma were superior to those found in the eyes $(\mathrm{P}<0.05)($ Table 3$)$.

The ELISA test using the S7 recombinant peptide detected antibodies anti- $L$. chagasi, expressed in optical density, in the aqueous humor of naturally infected dogs with high $\operatorname{IgG}$ titers. Some of these animals presented anti- $L$. chagasi $\operatorname{IgG}$ in the aqueous humor, independently of their presence in the plasma (Table 3).

As the Pearson's correlation coefficient was evaluated, regarding both right $(\mathrm{r}=0.828)$ and left $(\mathrm{r}=0.748)$ eyes, a significant positive correlation was observed when all the animals of this study were evaluated. It means that when the level of anti- $L$. chagasi antibodies increases in the plasma, it will also increase in the aqueous humor (Fig. 5). Both right $(\mathrm{r}=0.110)$ and left $(r=0.398)$ eyes of the animals with uveitis were evaluated and it was observed that the higher the level of anti-L. chagasi antibodies in the eye, the lower is its level in the plasma (Fig. 6). Although a significant correlation could not be confirmed.

The Goldman-Witmer coefficient (C) was used to verify the occurrence of local intraocular antibodies production. When $\mathrm{C}$ value is greater than one there is local production of intraocular antibodies (Hill et al., 1995). A C value greater than one was observed in $56 \%$ of the studied animals. Positive results from the aqueous humor and plasma samples were observed in $72 \%$ out of the 25 studied animals, from which two dogs were positive only to the aqueous humor test and another two only to the plasma test (Table 3). Paired analyses of the aqueous humor and plasma confirmed the diagnosis in $80 \%$ of the cases.

\section{DISCUSSION}

The frequency of the ocular alteration was low when compared to the results obtained by Molleda et al. (1993), reporting ocular alterations in $80.5 \%$ of the 41 animals with canine leishmaniasis. In a retrospective study, only $24.4 \%$ of the dogs infected by Leishmania infantum presented ocular alterations (Peña et al., 2000). The differences of these results are probably due to the pathogenicity of the Leishmania involved, or the duration and type of immune response developed by the animal. It is important to note that, in this study, ocular alterations due to canine calazar were predominantly bilateral. The larger frequency of bilateral involvement may be correlated to the systemic illness. However, it is known that in earlier stages of the disease only one of the eyes may be affected and bilateral involvement is common for the chronic cases (Molleda et al., 1993). 


\section{Brito et al.}

Table 1. Levels of total protein (mg/dl) of the aqueous humor of both right and left eyes of dogs infected by Leishmania (Leishmania) chagasi, Pernambuco State, Brazil, 2004

\begin{tabular}{lccccc} 
& \multicolumn{2}{c}{ Infected Group } & & \multicolumn{2}{c}{ Control Group } \\
\cline { 2 - 3 } \cline { 5 - 5 } & Mean & $\begin{array}{c}\text { Minimum- maximum } \\
\text { values }\end{array}$ & & Mean & $\begin{array}{c}\text { Minimum- maximum } \\
\text { values }\end{array}$ \\
\hline Right eye & $138.68 \pm 58.61 \mathrm{a}$ & $30-289$ & & $26.2 \pm 12.98 \mathrm{~b}$ & $10-53$ \\
Left eye & $149.88 \pm 56.27 \mathrm{a}$ & $66-270$ & & $25.52 \pm 12.43 \mathrm{~b}$ & $10-51$ \\
Mean & $144.28 \pm 16.24 \mathrm{a}$ & - & $25.86 \pm 3.59 \mathrm{~b}$ & - \\
\hline
\end{tabular}

Means in the same column with common letter do not differ $(\mathrm{P}>0.05)$ and means in the same row with no common letter differ $(\mathrm{P}<0.05)$ according to the Student test.

Table 2. Levels of total protein $(\mathrm{mg} / \mathrm{dl})$ of the aqueous humor of dogs naturally infected by Leishmania (Leishmania) chagasi with and without ocular signs, Pernambuco State, Brazil, 2003

\begin{tabular}{lccc}
\hline Ocular sign & $\mathrm{N}^{* *}$ & Mean & $\begin{array}{c}\text { Minimum-maximum } \\
\text { values }\end{array}$ \\
\hline Uveitis & 12 & $200.67 \pm 33.61 \mathrm{a}$ & $129-289$ \\
Other* & 26 & $134.77 \pm 16.96 \mathrm{~b}$ & $81-231$ \\
Without alteration & 12 & $108.5 \pm 32.78 \mathrm{~b}$ & $30-252$ \\
\hline Means in the
\end{tabular}

Means in the column with no common letters differ $(\mathrm{P}<0.05)$ according to Tukey test.

* Other signs: conjunctivitis, keratoconjunctivitis, keratoconjunctivitis sicca, keratitis, ulcerative keratitis.

** Number of eyes used to dose protein.

Table 3. Levels of antibodies to Leishmania chagasi, coefficient of Goldmann-Witmer and assertiveness in the aqueous humor and plasma of dogs naturally infected by Leishmania (Leishmania) chagasi, Pernambuco State, Brazil, 2004

\begin{tabular}{|c|c|c|c|c|c|c|c|}
\hline \multirow{2}{*}{ Animal } & \multicolumn{3}{|c|}{ Elisa* } & \multicolumn{2}{|c|}{ Value of $C^{* *}$} & \multicolumn{2}{|c|}{ Assertiveness } \\
\hline & $\mathrm{RE}$ & $\mathrm{LE}$ & Plasma & $\mathrm{RE}$ & LE & EYE*** & Plasma \\
\hline 1 & 0.177 & 0.081 & 0.231 & 0.8964935 & 0.420779 & + & + \\
\hline 2 & 0.145 & 0.158 & 0.162 & 1.0472222 & 1.17037 & + & + \\
\hline 3 & 0.142 & 0.136 & 0.115 & 1.4446957 & 1.41913 & + & + \\
\hline 4 & 0.131 & 0.153 & 0.051 & 3.0052941 & 3.6 & + & - \\
\hline 5 & 0.005 & 0.006 & 0.163 & 0.0358896 & 0.044172 & - & + \\
\hline 6 & 0.11 & 0.097 & 0.066 & 1.95 & 1.763636 & + & - \\
\hline 7 & 0.281 & 0.273 & 0.304 & 1.0814803 & 1.077632 & + & + \\
\hline 8 & 0.003 & 0.003 & 0.038 & 0.0923684 & 0.094737 & - & - \\
\hline 9 & 0.061 & 0.055 & 0.101 & 0.7066337 & 0.653465 & - & + \\
\hline 10 & 0.005 & 0.004 & 0.047 & 0.1244681 & 0.102128 & - & - \\
\hline 11 & 0.143 & 0.132 & 0.158 & 1.0589241 & 1.002532 & + & + \\
\hline 12 & 0.098 & 0.101 & 0.088 & 1.3029545 & 1.377273 & + & + \\
\hline 13 & 0.146 & 0.161 & 0.201 & 0.8498507 & 0.961194 & + & + \\
\hline 14 & 0.006 & 0.005 & 0.029 & 0.242069 & 0.206897 & - & - \\
\hline 15 & 0.097 & 0.099 & 0.155 & 0.7321935 & 0.766452 & + & + \\
\hline 16 & 0.001 & 0.011 & 0.015 & 0.078 & 0.88 & - & - \\
\hline 17 & 0.229 & 0.218 & 0.223 & 1.2014798 & 1.173094 & + & + \\
\hline 18 & 0.111 & 0.113 & 0.124 & 1.0473387 & 1.093548 & + & + \\
\hline 19 & 0.115 & 0.112 & 0.132 & 1.0193182 & 1.018182 & + & + \\
\hline 20 & 0.133 & 0.117 & 0.106 & 1.4680189 & 1.324528 & + & + \\
\hline 21 & 0.211 & 0.213 & 0.224 & 1.1020982 & 1.141071 & + & + \\
\hline 22 & 0.011 & 0.009 & 0.042 & 0.3064286 & 0.257143 & - & - \\
\hline 23 & 0.088 & 0.093 & 0.097 & 1.0614433 & 1.150515 & + & + \\
\hline 24 & 0.153 & 0.131 & 0.185 & 0.9676216 & 0.84973 & + & + \\
\hline 25 & 0.101 & 0.112 & 0.082 & 1.4410976 & 1.639024 & + & + \\
\hline
\end{tabular}

*Values of antibodies by ELISA test for cut point of optical density 0.072 ;* Coefficient of Goldmamm-Witmer.

$* * *$ Both eyes showed identical assertiveness; $\mathrm{RE}=$ Right eye; $\mathrm{LE}=$ Left eye. 


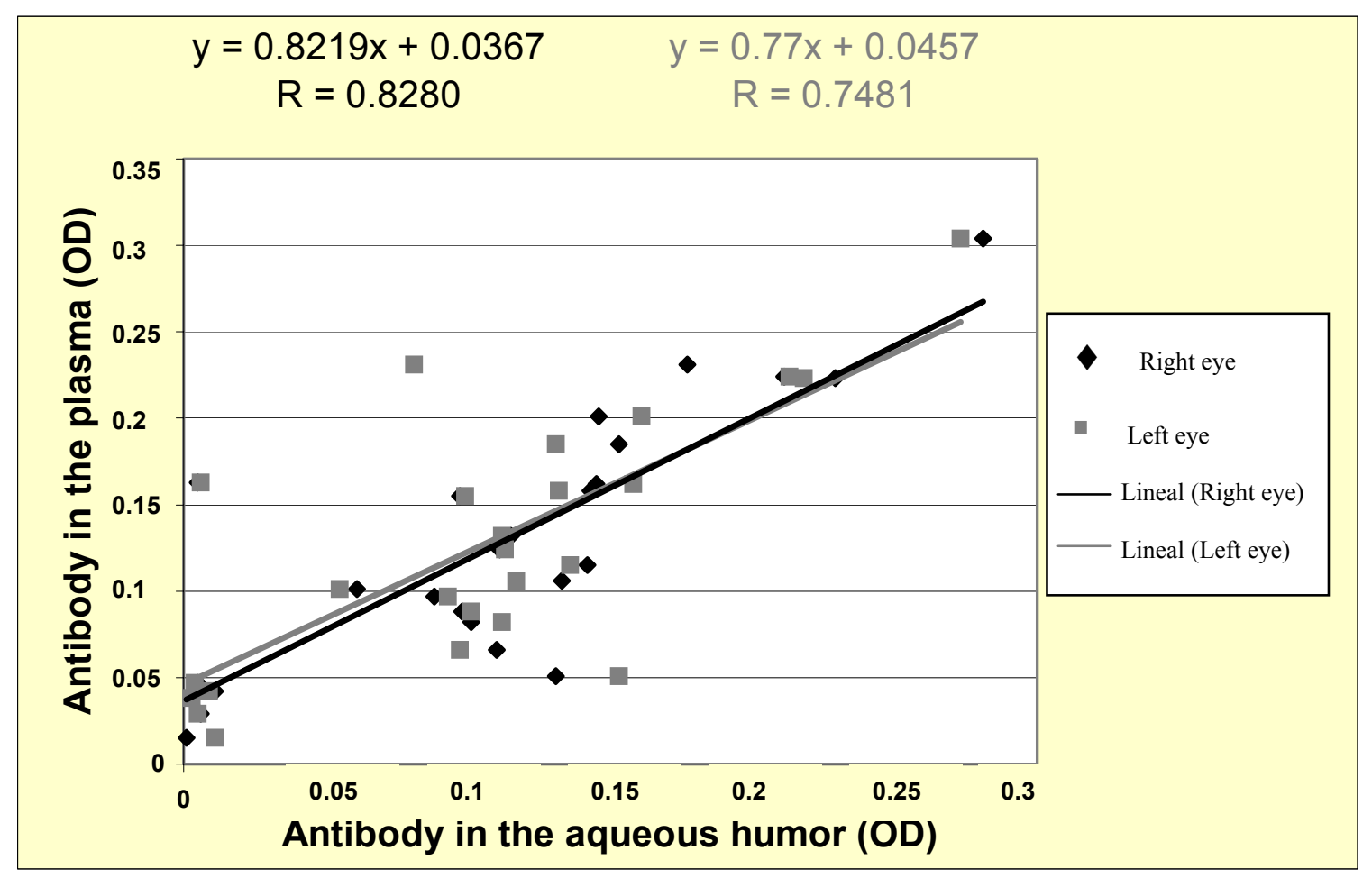

Figure 5. Pearson's correlation coefficient among the level of anti-L. chagasi antibodies measured by optical density (OD) in the plasma and in the aqueous humor of dogs naturally infected by Leishmania (Leishmania) chagasi, using the ELISA/S7, Pernambuco State, Brazil, 2004.

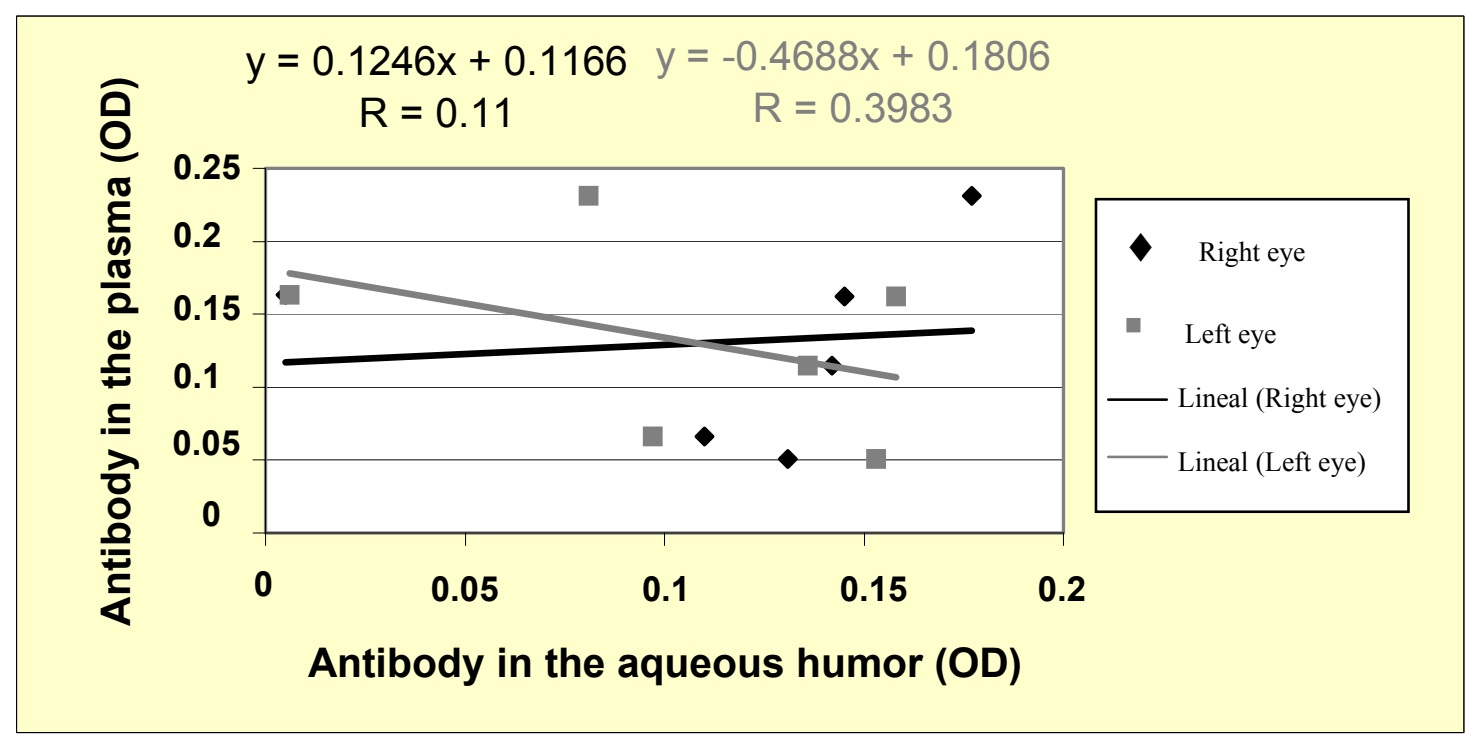

Figure 6. Pearson's correlation coefficient among the level of anti-Leishmania (Leishmania) chagasi antibodies measured by optical density (OD) in the plasma and in the aqueous humor of dogs with uveitis, naturally infected by Leishmania (Leishmania) chagasi, using ELISA/S7, Pernambuco State, Brazil, 2004. 
Uveitis was the most frequent ophthalmic finding, as observed in other studies (Molleda et al., 1993; Feitosa et al., 2000). In dogs with ocular and periocular alterations associated to CVL, anterior uveitis occurred in a frequency of $42 \%$ (Peña et al., 2000), which was a higher rate than that obtained in this study. Nevertheless, up to $70 \%$ of the dogs with visceral leishmaniasis from endemic areas may present uveitis. Immune complex deposition on vascular walls may cause uveitis in dogs with leishmaniasis (Pumarola et al., 1991; Garcia-Alonso et al., 1996). Hyphema is also a common finding in dogs with CVL. Eyelid lesions were identified. Blepharitis has been described as one of the most common findings in canine calazar (Ferrer, 1999).

Conjunctival lesions have been frequently identified in CVL dogs. In this study, around 75.6\% of dogs were infected by Leishmania spp. In spite of being an isolated finding, conjunctival inflammation was observed in only $34.1 \%$ of the animals (Molleda et al., 1993). Keratoconjunctivitis sicca in visceral leishmaniasis may sometimes be due to lacrimal glands inflammation or obstruction of their secretory ducts (Molleda et al., 1993). In spite of the rare isolated involvement of the cornea, similar lesions were also found by other authors (Molleda et al., 1993; Peña et al., 2000).

Unlike other systemic diseases with ocular manifestations, leishmaniasis shows some preference for the anterior chamber of the eye (Puchol and Gonzáles, 1989). In this study, only one animal presented posterior chamber lesion. Ocular conditions were not observed in some of the studied dogs. It is known that the absence of ocular signs may occur in $10-50 \%$ of the canine population because of natural resistance to infection (Abranches et al., 1991). Interleukin-2 (IL-2) and tumor necrosis factor alpha (TNF- $\alpha$ ) play an important role on protection against clinical disease (Pinelli et al., 1994).

The level of total protein of the aqueous humor of control group animals was within normal values as described by other authors (Hazel et al., 1985; Krohne et al., 1995). However, there are no data for dogs with leishmaniasis. In this study, dogs naturally infected by L. chagasi presented higher aqueous humor total protein values than clinically healthy dogs. Animals naturally infected by Leishmania spp. showed a higher total protein level than clinically healthy animals, which is in agreement with Novalis et al. (1994). The mean, of the total protein of dogs presenting conjunctivis, keratoconjunctivitis, keratoconjunctivitis sicca, keratitis, ulcerative keratitis were $134.77 \pm 16.96 \mathrm{mg} / \mathrm{dl}$, which was statistically different from those found in the control group. Previous research comparing the mean protein values of the aqueous humor of healthy and Leishmania infantum infected dogs did not find significant differences (Novalis et al., 1994). In this study, the total protein mean value verified in the aqueous humor of dogs presenting uveitis and visceral leishmaniasis was $200.67 \pm 33.61 \mathrm{mg} / \mathrm{dl}$. Similar values $(231.8 \mathrm{mg} / \mathrm{dl})$ were also found by other authors (Novalis et al., 1994).

The severity in which the aqueous humor barrier is broken may increase with protein concentration (Dernouchamps, 1982). This might be due to iris and ciliary vessel dilation (Krohne and Vestre, 1987), due to the presence of the parasite or deposition of immune complexes in the iris stroma (Molleda et al., 1993). Increase of total protein may also be correlated to the great amount of plamocytes at the ciliary body (Brito et al., 2004).

The recombinant ELISA technique used in this study was effective. Previous studies using ELISA showed a high titer of anti-Leishmania IgG in the aqueous humor of dogs presenting uveitis (Garcia-Alonso et al., 1995; GarciaAlonso et al., 1996). Antibody detection in the aqueous humor of dogs presenting uveitis, despite of the level of antibody in the serum, may be related to the uveitis found in sick animals (Garcia-Alonso et al., 1996). In this study, specific antibodies were found in the aqueous humor of infected dogs presenting uveitis, but not in the plasma.

Studies using single radial immunodiffusion technique did not find a significant correlation between IgG values in the aqueous humor and plasma (Lopes et al., 1993). By ELISA, specific levels of anti-Leishmania antibodies in the aqueous humor and serum showed a positive and statistically significant correlation, which suggests a direct participation of the immunomediated response by antibodies (Garcia-Alonso et al., 1998). Specific antibody detection in the aqueous humor may be useful in ocular infection diagnosis (Hill et al., 1995). 


\section{CONCLUSIONS}

Uveitis and other ophthalmopathies, mainly of the anterior chamber of the eye, must be considered as a differential diagnosis in visceral leishmaniasis of animals from the endemic areas. The procedure for dosage of total protein of the aqueous humor is easy to perform and the values obtained in the infected animals may be used as a complementary exam for dogs infected by Leishmania (Leishmania) chagasi. It can be still admitted that intraocular immunogenic factors are associated to the uveitis in dogs with visceral leishmaniasis. Canine visceral leishmaniasis diagnosis may be aided by the use of the ELISA technique, using the S7 recombinant peptide being worth for the aqueous humor.

\section{REFERENCES}

ABRANCHES, P.; SANTOS-GOMES, G.; RACHAMIN, N. et al. An experimental model for canine visceral leishmaniasis. Parasite. Immunol., v.13, p.537-550, 1991.

BLOGG, J.R.; COLES, E.H. Clinicopathological aspects of canine aqueous humour proteins. Res. Vet. Sci., v.12, p.95100, 1971.

BRADFORD, M.M. A rapid and sensitive method for the quantitation of microgram quantities of protein utilizing the principal of protein-dye binding. Anal. Bioch., v.72, p.248254, 1976.

BRITO, F.L.C.; ALVES, L.C.; ORTIZ, J.P.D. et al. Uveitis associated by Leishmania chagasi in dog from Olinda City, Pernambuco, Brazil. Ciên. Rural, v.34, p.925-929, 2004.

CARMAGO, M.E. Cross-reactivity in immunofluorescense for Tryposoma and Leishmania antibodies. Am. J. Trop. Med. Hyg., v.18, p.500-505, 1977.

DERNOUCHAMPS, J. The proteins of the aqueous humor. Doc. Ophthalmol., v.53, p.1993-248, 1982.

FEITOSA, M.M.; IKEDA, F.A.; LUVIZOTTO, M.C. et al. Aspectos clínicos de cães com leishmaniose visceral no município de Araçatuba - São Paulo (Brasil). Clin. Vet., v.28, p.36-42, 2000 .

FERRER, L. Clinical aspects of canine leishmaniasis. In: INTERNATIONAL CANINE LEISHMANIASIS FORUM, 1., 1999, Barcelona. Proceedings... Barcelona, 1999. p.6-10.

GARCIA-ALONSO, M.; BLANCO, A.; RINA, D. et al. Immunopathology of the uveitis in canine leishmaniasis.Parasite. Immunol, v.18, p.617-623, 1996.

GARCIA-ALONSO, M.; NIETO, C.G.; VERDUGO, S.G. et al. Diagnostico y tratamiento de la uveítes anterior inmunomediada en leishmaniosis canina. In: CONGRESSO IBÉRICO DE PARASITOLOGÍA, 4., 1995. Anais... 1995. p.198.

GARCIA-ALONSO, M.; MIRÓN, C., MOLANO, I. et al. Patología ocular asociada a leishmaniosis canina. Cons. Dif. Vet., v.6, p.49-53, 1998.

HAZEL, S.J.; THRALL, M.A.; SEVERIN, G.A. et al. Laboratory evaluation of aqueous humor in the healthy dog, cat, horse, and cow. Am. J. Vet. Res., v.3, p.657-659, 1985.

HILL, S.L.; LAPPIN, M.R.; CARMAN, J. et al. Comparasion of methods for estimation of Toxoplasma gondii- specific antibody production in the aqueous humor of cat. Am. J. Vet. Res., v.56, p.1181-1187, 1995.

KROHNE, S.D.G.; VESTRE, W.A. Effects of flunixin meglumine and dexamethasone on aqueous protein values after intra-ocular surgery in the dog. Am. J. Vet. Res., v.48, p.420-422, 1987.

KROHNE, S.G.; KROHNE, D.T.; LINDLEY, D.M. et al. Use of laseer flaremetry to measure aqueous humor concentration in dog. J. Am. Vet. Med. Assoc., v.206, p.11671172, 1995.

LOPES, R.; NOVALES, M.; GINEL, P.J. et al. Concentrations d'immunoglobulines dans le plasma et l'humeur aqueuse de chiens atteints de leishmaniose. Rev. Méd. Vet., v.144, p.621-623, 1993.

MOLLEDA, J.M.; NOVALES, M.; GINEL, P.J. et al. Clinical and histopathological study of the eye in canine leishmaniasis. Isr. J. Vet. Med., v.48, p.173-178, 1993.

NOVALIS, M.; LOPEZ, R.; GINEL, P.J. et al. Les effets de l'uvéite sur la concentration des proteins totales dans l'humeur aqueuse de chiens atteints de leishmaniose. Rev. Méd. Vet., v.145, p.257-259, 1994.

PEÑA, M.T.; ROURA, X.; DAVIDSON, M.G. Ocular and periocular manifestations of leishmaniasis in dog: 105 cases (1993-1998). Vet. Ophthalmol, v.3, p.35-41, 2000.

PINELLI, E.; KLILLICK-KENDRICK, R.; WAGENNAAR, J. et al. Cellular and humoral immune responses in dogs experimentally and naturally infected with Leishmania infantum. Infect. Immun., v.62, p.229-235, 1994.

PUCHOL, J.L.; GONZALEZ, J.L. Leishmaniasis ocular: afeciones del segmento anterior. In: NATIONAL. CONGRESS ASOCIACIÓN DE VETERINARIOS ESPANÕLES ESPECIALISTAS EN PEQUENOS ANIMALES, 1989, Barcelona. Proceedings...Barcelona: AVEPA, 1989. p.115-122.

PUMAROLA, M.; BREVIK, L.; BADIOLA, J. et al. Canine Leishmaniasis associated with systemic vasculitis in two dogs. J. Comp. Pathol., v.105, p.279-286, 1991.

WORLD Health Organization, 2003. Disponível em: www.who.int/emc/diseases/leish/ leishmaniasis.pdf> Acessado em: 20/11/2003. 